\title{
Konsep Invasi Ruang Eventual: Fleksibilitas Penggunaan Ruang pada Perancangan Rusunawa
}

\section{Eventuality Space Invasion Concept: The Flexible Use of Low-Cost Flat Building Design}

\author{
Joshua Gama Wastara \\ Institute Teknologi Sepuluh Nopember, Surabaya, Indonesia, joshuawastara@gmail.com \\ Aarina Hayati*
}

Arina Hayati, Departemen Arsitektur, Institut Teknologi Sepuluh Nopember, Surabaya, Indonesia, arina h@arch.its.ac.id

*correspondence author

\begin{abstract}
Spatial invasion is a subjective expression of low-income communities in the riverbank areas. This lifestyle is one of the expressions of society to meet the lack of spatial space in residential areas, especially in riverbank areas. The previous study stated several things, the invasion of the lifestyle of the riverside community has occurred especially when the settlements were divided spatially. Besides, the precedent for the rusunawa in Surabaya shows its design by providing spaces that connected spaces, units, and buildings, which are usually invaded by the inhabitants for domestic and social activities. Qualitative studies were obtained to find the configuration of spatial invasion through activity observations and indepth interviews with several participants living in riverbank settlements. This study analyses whether the use of space in the flat can be designed under similar activities and the use of spatial intervention in the kampung settlement, in this context near the river border. The results showed that there were similarities in the use of public spaces in residential areas and rusunawa, namely eventual space invasion that is used as the design concept. Shared space for community activities in the settlements can be adopted and provided in flat design with the support of several architectural elements. These expressions are then simulated into several concept illustrations of a flat design proposal with several required conditions. The result proposes several potentials of space in the flat that can be used for domestic and social interests.
\end{abstract}

Keywords: space invasion, flexible space, eventual space

Abstrak

Invasi spasial merupakan ekspresi subyektif dari masyarakat berpenghasilan rendah di daerah bantaran sungai. Kebiasaan atau gaya hidup ini merupakan salah satu ekspresi masyarakat untuk memenuhi kurangnya ruang spasial di lingkungan permukiman terutama di daerah bantaran sungai. Studi sebelumnya menyatakan beberapa hal, invasi gaya hidup masyarakat tepi sungai terjadi terutama ketika ruang permukiman digunakan berbagi. Selain itu, studi preseden rusunawa di Surabaya menunjukkan keberadaan ruangruang sebagai penghubung antar ruang, antar unit, dan antar bangunan, dimana ruang ruang tersebut biasanya diinvasi oleh penguni untuk aktivitas domestik maupun sosial. Studi kualitatif dilakukan untuk menemukan konfigurasi invasi spasial melalui kegiatan observasi dan wawancara mendalam dengan beberapa partisipan yang tinggal di pemukiman tepi sungai.Penelitian ini menganalisa apakah penggunaan ruang di rusunawa dapat didesain dan diperlakukan seperti aktivitas dan intervensi penggunaan ruang di kampung, dalam konteks di sempadan sungai. Hasil penelitian menunjukkan terdapat kesamaan penggunaan ruang publik di pemukiman warga dan rusunawa. Ruang tersebut menjadi konsep dalam penelitian ini, yaitu eventual space invasion. Ruang bersama untuk aktivitas masyarakat di permukiman dapat disediakan di bangunan rusunawa dengan dukungan beberapa elemen arsitektur. Ekspresi ini kemudian disimulasikan ke dalam

Konsep Invasi Ruang Eventual: Fleksibilitas Penggunaan Ruang pada Perancangan Rusunawa 
beberapa ilustrasi konsep rancangan bangunan rusunawa dengan menerapkan beberapa kriteria. Hasil akhir mengusulkan beberapa potensi ruang di rusunawa yang bisa digunakan untuk kepentingan domestik maupun sosial.

Kata Kunci: Invasi ruang, ruang fleksibel, eventual space

Received: 2021-02-27 | Accepted: 2021-08-29 | DOI: 10.29080/eija.v7i1.1187 | Page: 12-25

EMARA: Indonesian Journal of Architecture

http://jurnalsaintek.uinsby.ac.id/index.php/EIJA

This article is open access distributed under the terms of the Creative Commons Attribution ShareAlike 4.0 International License, which permits unrestricted use, distribution, and reproduction in any medium provided the original work is properly cited.

\section{Pendahuluan}

Kampung illegal merupakan salah satu permasalahan yang memicu tumbuhnya area kumuh di perkotaan. Di samping itu, penghuni di permukiman tersebut cenderung tidak ingin pindah dan tetap bertahan walaupun kondisi dan kualitas permukiman tidak memadai dan ilegal (Wastara, 2020). Gaya hidup masyarakat secara tidak langsung terbentuk dari kebiasaan hidup dan aktivitas-aktivitas harian yang dilakukan oleh masyarakat di kampung ilegal. (Das, 2015) menyatakan kebiasaan/gaya hidup masyarakat mempengaruhi bagaimana mereka memilih dan menentukan dimana mereka tinggal. Sebagai contoh hasil penelitian (Das, 2017) menunjukkan warga kampung yang hidup di lingkungan permukiman bantaran sungai selalu menolak adanya relokasi hunian oleh pemerintah karena mereka menganggap kebiasaan hidup dan aktivitas mereka tidak bisa terpenuhi ketika pindah ke hunian komunal. Walaupun menurut(Hutagalung, 2007). relokasi hunian berupa rusunawa yang dirancang oleh pemerintah dirancang untuk memenuhi kebutuhan dasar penghuni termasuk privasi, sistem utilitas, dan keamanan. Penolakan ini terjadi karena menurut (Maslow, 2010), terdapat beberapa kebutuhan manusia yang lebih bersifat perseptual dan subjektif, termasuk masyarakat yang tinggal di permukiman informal dan berpenghasilan menengah kebawah.

Penyediaan hunian vertikal menjadi salah satu solusi untuk mengurangi permasalahan kekumuhan, dan memberikan hunian yang layak kepada semua warga kota yang merupakan hak asasi manusia (Das, 2017). Selain itu, hal ini sesuai dengan Visi Kota Surabaya ke-5 yang menyebutkan "Memantapkan sarana dan prasarana lingkungan dan permukiman yang ramah lingkungan"(Pemkot Sutrabaya, 2017). (Maslow, 2010) juga menekankan hunian sebagai kebutuhan dasar dapat mengekspresikan identitas dan aktualisasi diri manusia. Sehingga, penyediaan hunian vertikal menjadi relevan untuk merespon isu kepadatan dan kebutuhan hunina dengan mempertimbangkan konteks sosial, ekonomi, dan budaya penghuni.

Diskusi dalam paper ini merupakan bagian dari penelitian berbasis perancangan untuk menggali kebiasaan bermukim dan berhuni terutama dalam hal invasi ruang di permukiman ilegal dan rumah susun di Surabaya. Hasil dari penelitian ini kemudian dirumuskan menjadi konsep dan kriteria perancangan untuk hunian vertikal komunal terutama pada aspek penggunaan dan penataan ruang. Sehingga terdapat dua pertanyaan penelitian, yaitu pertama, bagaimana kebutuhan bermukim dan berhuni oleh masyarakat yang tinggal 
di permukiman ilegal dan rumah susun di Surabaya? Kedua, apa saja aspek-aspek kebiasan dan kebutuhan bermukim dan berhuni dua konteks hunian tersebut dapat dirumuskan sebagai konsep dan kriteria untuk menentukan rancangan hunian vertikal?

Fenomena yang sering terjadi pada perkampungan di Surabaya, adalah kegiatan saling memasuki dan beraktivitas pada area hunian lain (Das, 2015, 2017). Salah satu contoh adalah aktivitas terkait pekerjaan warga di Kampung Juwingan di (Das, 2017). Aktivitas ini merupakan aktivitas yang disepakati bersama untuk kebutuhan bersama dan saling menguntungkan. Hasil penelitian(Lianto \& Dwisusanto, 2015) juga memaparkan kebiasaan penghuni kampung di Surabaya salah satunya adalah invasi ruang baik di area pribadi maupun area tetangga. Hal ini menunjukkan kegiatan invasi ruang menjadi kebutuhan khusus sesama warga untuk mengakomodasi kebutuhan dan aktivitas bermukim(Lianto \& Dwisusanto, 2015). Selain itu, menurut (Kisnarini, 2015) masyarakat yang tinggal di kampung atau rumah susun melakukan invasi fisik karena adanya motivasi pemenuhan kebutuhan ruang untuk aktivitas domestik, sosial, ekonomi.

Pertumbuhan dan proses kehidupan dalam berhuni membutuhkan hunian yang dapat beradaptasi dan menyesuaikan proses kehidupan manusia. Sehingga, konsep ruang yang fleksibel menjadi relevan untuk mengakomodasi kebutuhan tersebut. Berdasarkan Hertzberger dalam (Ćetković, 2012) konsep fleksibilitas menandakan penolakan terhadap gagasan yang baku pada sebuah standar (gambar1), misalkan, dinding adalah elemen masif yang tidak dapat dipindahkan, sedangkan dalam gagasan fleksibilitas, dinding dapat diubah atau disesuaikan sesuai kebutuhan. Meskipun fleksibilitas ini berarti transformasi dalam rancangan, bukan berarti selalu melibatkan penggunaan teknologi. Fleksibilitas dapat berupa interaksi dengan penggunanya, pengajuan inovatif dan ekspresif dari desain kontemporer. Bangunan fleksibel dimaksudkan untuk merespons perubahan situasi dalam penggunaan, pengoperasian, atau lokasinya (Kronenburg, 2007).

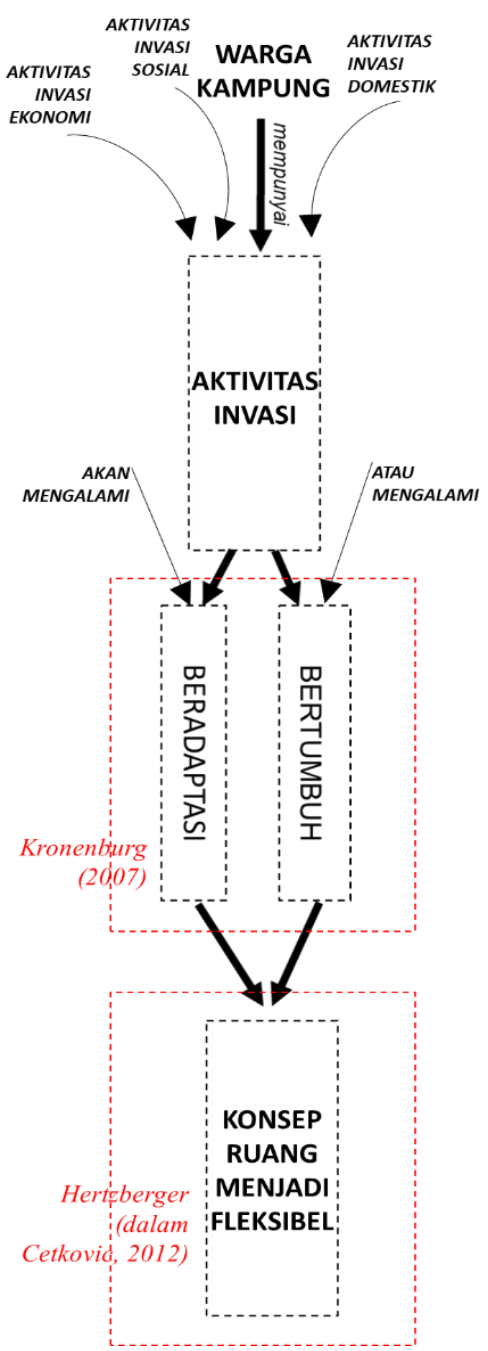

Gambar 1. Diagram Pengaruh Invasi pada Konsep Fleksibilitas (Wastara, 2020)

Dari penjelasan(Kronenburg, 2007) memungkinkan kegiatan invasi ruang merupakan salah satu ekspresi dalam penggunaan ruang yang fleksibel dan dapat menyesuaikan/beradaptasi sesuai dengan kebutuhan. Kegiatan ini dapat 
merubah fungsi dan makna ruang yang tidak dilihat sebagai fungsi tunggal, namun dapat menjadi multi fungsi dan makna. Sehingga, konsep ruang fleksibel dapat menjadi representasi aktivitas invasi ruang terutama dalam hal kegiatan interaksi dan aktivitas pengguna dalam penggunaan ruang Hertzberger dalam(Ćetković, 2012).

\section{Metode}

Penelitian menggunakan metode kualitatif deskriptif dimana hasil penelitian kemudian dijadikan sebagai kriteria dan konsep perancangan rumah susun sewa (rusunawa). Penelitian ini dilakukan dengan observasi lapangan di setting natural dan hasil dianalisa secara deskriptif (Creswell, 2014). Dalam perancangan arsitektur, penggunaan penelitian kualitatif merupakan bagian dari design by research pada awal tahapan proses merancang (Jormakka et al., 2014). Design research didasari memasukkan eksplorasi fenomena melalui riset ke dalam proses desain untuk mengembangkan metode dan menentukan konsep rancangan. Menurut (Plomp, 2007) design research adalah suatu kajian sistematis tentang merancang, mengembangkan dan mengevaluasi intervensi riset sebagai solusi untuk memecahkan masalah yang kompleks dalam praktik pendidikan. Sintesa hasil observasi lapangan dan studi literatur/preseden kemudian dirumuskan sebagai hipotesa perancangan untuk mendukung kerangka kerja proses perancangan berbasis konsep/conceptbased framework (Plowright, 2014).

Tahapan pertama adalah mengajukan permasalahan perancangan yaitu respon kebutuhan hunian dan isu kepadatan serta gaya hidup berhuni dan bermukim masyarakat marginal. Untuk menggali kedalaman informasi, maka penelitian empiris dilakukan dengan menggunakan pendekatan arsitektur perilaku sebagai dasar merumuskan sudut pandang kritik dalam merancang hunian sesuai dengan kebutuhan masyarakat tertentu. Pendekatan ini menekankan perlunya memahami manusia atau masyarakat dalam memanfaatkan ruang secara empiris (Haryadi, 2010). Berdasarkan penjelasan design research oleh Christopher Alexander dalam (Jormakka et al., 2014) kajian empiris di lapangan untuk memperoleh detail ekspresi dari aktivitas invasi spasial yang dilakukan oleh masyarakat menegah kebawah, di permukiman marginal sempadan sungai. Lokasi penelitian di pemukiman medokan semampir indah tangkis tepi sungai di Surabaya. Disamping melakukan pengamatan, wawancara mendalam terhadap 8 parsipan dan melakukan dokumentasi foto dan sketsa kondisi aktivitas dan settingnya. Taktik-taktik tersebut untuk menggali Invasi ruang baik untuk aktivitas domestik, sosial maupun ekonomi.

Selanjutnya, studi literatur dan kajian preseden dari 9 (sembilan) preseden bangunan rusun di kota Surabaya dilakukan untuk memperdalam argumentasi hasil penelitian empiris yaitu mencari pola penggunaan ruang, fleksibilitas ruang dan invasi ruang. Studi preseden ditelaah dari aspek yang sama dengan studi lapangan, yaitu aktivitas invasi ruang pemukiman sempadan sungai. Hasil dari studi empiris kualitatif, studi literatur dan kajian preseden rusunawa kemudian dianalisis secara deskriptif dan rumusan hasil dikomunikasikan menjadi diagram dan sketsa untuk mendukung penentuan konsep dasar perancangan yaitu salah satunya konsep fleksibilitas spasial.

\section{Hasil dan Pembahasan}




\section{Observasi jenis invasi ruang pada subjek penelitian}

Observasi lapangan yang

dilakukan (Wastara, 2020). masyarakat yang tinggal di permukiman sempatan sungai di sekitar kampung Medokan Semampir Indah Tangkis, Surabaya, melakukan invasi spasial dengan temuan beberapa poin utama, sebagai berikut:

1) Partisipan menyukai desain rumah yang terbuka, mendukung keleluasaan melakukan aktivitas, dan memiliki penghawaan alami, tetapi kebutuhan privasi tetap terjaga dengan memberi batasan view dari luar. Kriteria ini membuktikan pernyataan (Kopec, 2018) bahwa masyarakat Indonesia lebih memilih tatanan hunian terbuka dan dekat dengan lingkungan alami, namun kebutuhan privasi tetap terjaga.

2) Invasi spasial melibatkan beberapa aktivitas dilakukan di satu setting/tempat dalam waktu berbeda. Temuan ini mendukung hasil penelitian dari (Lianto \& Dwisusanto, 2015)

3) Invasi ruang dilakukan selalu didasari kesepakatan legal secara lisan. Hal ini memberikan indikasi bahwa kegiatan ini tidak bersifat ilegal, karena dalam KBBI pengertian invasi merupakan kegiatan memasuki wilayah lain dengan maksud menyerang atau menguasai area tersebut (KBBI, n.d.). Hasil ini didukung oleh(Lianto \& Dwisusanto, 2015) yang menyatakan dalam kehidupan di permukiman horisontal maupun vertikal, terutama pada rumah susun sederhana, seringkali terjadi pelanggaran teritorialitas dan perebutan teritori terutama pada daerah perbatasan teritorial. Hal tersebut dilakukan dapat secara sengaja maupun tidak sengaja, dengan adanya kesepakatan dan kondisi tertentu.

4.) Invasi spasial memberi aturan penggunaan fleksibel sebuah setting untuk aktivitas tertentu. Sehingga, aktivitas yang terjadi hanya aktivitas yang dibutuhkan saja, dimana pada waktu tertentu aktivitas dapat dilakukan bersamaan dengan aktivitas lain atau bersamaan dengan pengadaan/penataan perabotan lain. Temuan ini didukung dan membuktikan teori (Kronenburg, 2007), yang menjelaskan fleksibilitas dapat berupa penggunaan, inovasi dan ekspresi dari desain kontemporer. Di samping itu, penggunaan fleksibel pada ruang publik (jalan kampung) juga ditunjukkan oleh penelitian (Ramadhani et al., 2019); dimana jalan kampung pada saat tertentu tidak hanya menjadi ruang sirkulasi, tetapi juga dimanfaatkan untuk aktivitas domestik (mencuci baju, sepeda, menjemur pakaian) dan juga melakukan kegiatan ekonomi untuk tujuan wisata.

Selain itu, ada beberapa ekspresi perilaku masyarakat khusus di permukiman sempadan sungai. Pertama, beberapa warga menjadikan elemen rumah terutama furnitur dan partisi secara fleksibel untuk pemenuhan kebutuhan beraktivitas sehari-hari. Temuan ini didukung oleh(Frick \& Mulyani, 2006) yang menyatakan pertumbuhan hidup manusia dapat berupa adaptasi pada perubahan - perubahan kehidupan. Baum et al., (1974) juga menyatakan fitur arsitektur semi-fixed/partisi dan perilaku/aktivitas seseorang digunakan melakukan invasi ruang baik secara aktif dan pasif. Kedua, warga masih menjaga privasi dengan berbagai ekspresi, baik di area gang/selasar kampung maupun area/selasar di bantaran sungai. 


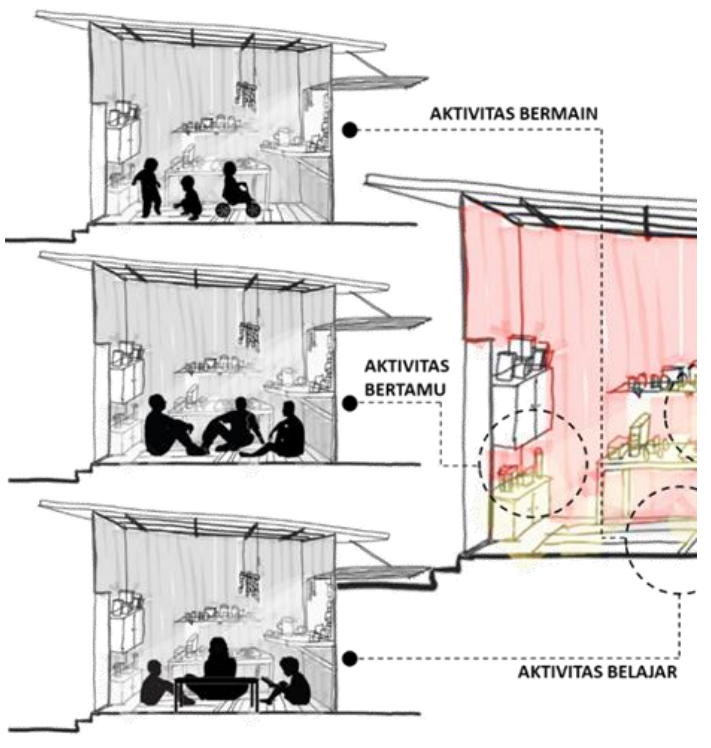

Gambar 2. Aktivitas bermain, belajar dan bertemu dalam setting yang sama (Wastara, 2020)

Lianto \& Dwisusanto, (2015) menjelaskan pada kondisi tertentu penghuni menghargai batasan teritorial masingmasing walaupun tanpa kejelasan batas fisik dengan toleransi tinggi.

Dari hasil observasi dapat disimpulkan bahwa beberapa aktivitas dapat dilakukan di satu tempat dengan melakukan invasi spasial pada waktu tertentu. Sebagai contoh Gambar 2 dan Gambar 3 menunjukkan akibat kurangnya area ruang untuk menampung berbagai aktivitas domestik, maka invasi spasial diterapkan dengan penggunaan ruang secara fleksibel. Konsep privasi untuk tiap ruang dapat berubah seiring dengan perubahan penggunaannya (menerima tamu, beristirahat/tidur, bermain, belajar dan lain-lain). Gambar 1 dan 2 juga menunjukkan salah satu ruang depan di rumah partisipan dapat digunakan untuk mengakomodasi beberapa kegiatan dengan melakukan perubahan setting atau menambah furnitur. Pada area/setting yang sama, sebuah ruang dapat 'diinvasi' oleh penghuni tidak hanya untuk kegiatan domestik (tidur, menyimpan barang, melihat TV, berkumpul dengan keluarga, merawat anak dan lain sebagainya), namun juga untuk kegiatan/aktivitas ekonomi (warung) dan aktivitas sosial (bertamu atau ngobrol/berbincang dengan tetangga) pada waktu yang sama ataupun berbeda.

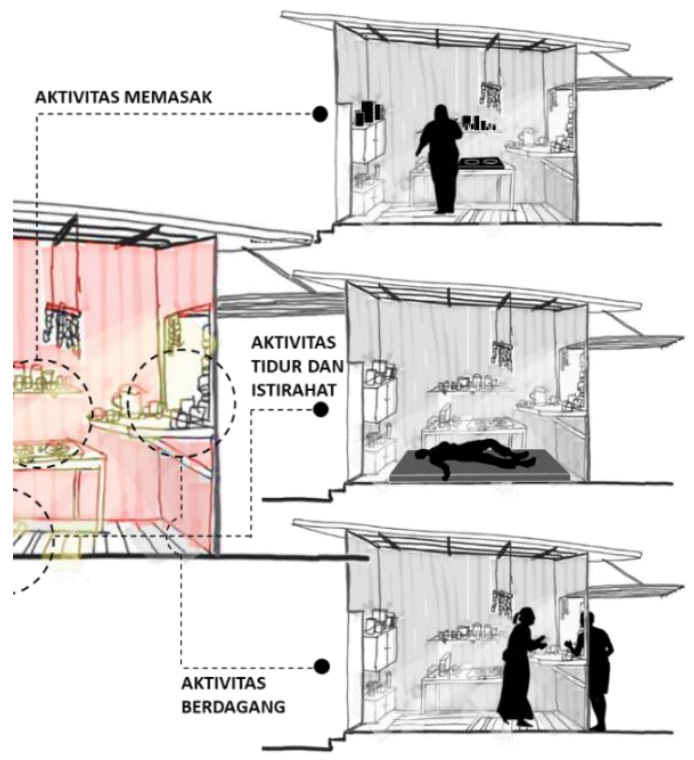

Gambar 3. Kegiatan memasak, beristirahat dan berdagang/aktivitas ekonomi dilakukan di setting yang sama pada waktu berbeda (Wastara, 2020).

Diskusi berikutnya adalah pembahasan kajian preseden dari beberapa rusunawa di Kota Surabaya. Tujuan dari kajian ini untuk merumuskan jenis penggunaan dan fleksibilitas ruang dan aktivitas invasi ruang di hunian rusunawa di Kota Surabaya. Konsep fleksibilitas yang diobservasi adalah fleksibilitas dalam penggunaan dan penataan program ruang serta fleksibilitas dalam melakukan invasi ruang. Dari studi terhadap 9 (sembilan) preseden rusunawa di kota Surabaya terdapat beberapa poin yang menunjukkan penggunaan ruang untuk mengakomodasi aktivitas penghuni dan juga sebagai ruang penghubung antar area. Penggunaan secara fleksibel di rusunawa mempertimbangkan keberagaman dari kebiasaan penghuni 
rusunawa untuk dapat diakomodasi karena keterbatasan ruang, sehingga ruang-ruang tersebut menjadi ruang yang digunakan bersama - sama. Hubungan antar ruang dibagi menjadi tiga (Tabel 1). Pertama, hubungan ruang di dalam unit (mikro) adalah penghuni melakukan penyekatan ruang dalam secara fleksibel dengan dapat merubah ataupun memindah perabotan dan menggunakan material ringan untuk partisi. Kedua, hubungan ruang di lingkup antar unit hunian (meso) yaitu diwakili adanya selasar terbuka dan ruang void di tengah bangunan rusunawa. Ketiga, hubungan ruang di lingkup antar bangunan (Makro) berupa balkon, teras, halaman bersama di lantai dasar untuk mengakomodasi aktivitas berinteraksi antar penghuni dan kegiatan bersama.

Beberapa invasi spasial pada hunian rusunawa dianalisa dan digolongkan menjadi 3 (tiga) jenis klasifikasi aktivitas, yaitu domestik, ekonomi, dan sosial (Tabel 1). Aktivitas domestik mencakup meletakkan jemuran pada balkon (1C, 1D), dan meletakkan barang di sekitar selasar rusunawa. Aktivitas sosial termasuk aktivitas bercengkrama/berinteraksi antar penghuni dewasa di area balkon/selasar yang menghubungkan antar bangunan (1C, 1D, 1E), aktivitas bermain anak - anak di selasar yang memiliki lebar lebih dari 4 meter (1I, 1J, 10), dan juga warga dapat bermain dan berkumpul di taman rusunawa di lantai dasar (1Q). Keberadaan aktivitas sosial ini perlu dijaga karena sebuah rusun sebaiknya dapat mengakomodasi dan membentuk tatanan sosial keagamaan, rasa guyup dan tolong penolong, bukan mengutamakan aspek ekonomi/bisnis (Prasetyo, 2017).

Beberapa elemen arsitektur yang terdapat di rusunawa dan dimanfaatkan untuk melakukan proses invasi ruang antara lain: ruang hunian yang dibagi dengan batasan perabotan/furnitur $(1 \mathrm{~A}, 1 \mathrm{M})$, balkon/selasar di setiap unit yang dapat digunakan sebagai ekspansi area berkumpul/interaksi sosial (1L, 2B, 2C), ruang bersama di beberapa lantai rusunawa sebagai ruang dengan aktivitas yang fleksibel (1B, 2A), lantai dasar dengan dilengkapi penutup atap yang transparan untuk melindungi dari panas dan hujan $(1 \mathrm{H})$, koridor sebagai area penghubung serta ekspansi aktivitas sosial dan domestik oleh (2D, 2F) serta teras dengan lebar 2 sampai 4 meter untuk menyediakan ventilasi udara dan area pandang ke dalam atau keluar bangunan $(2 G)$.

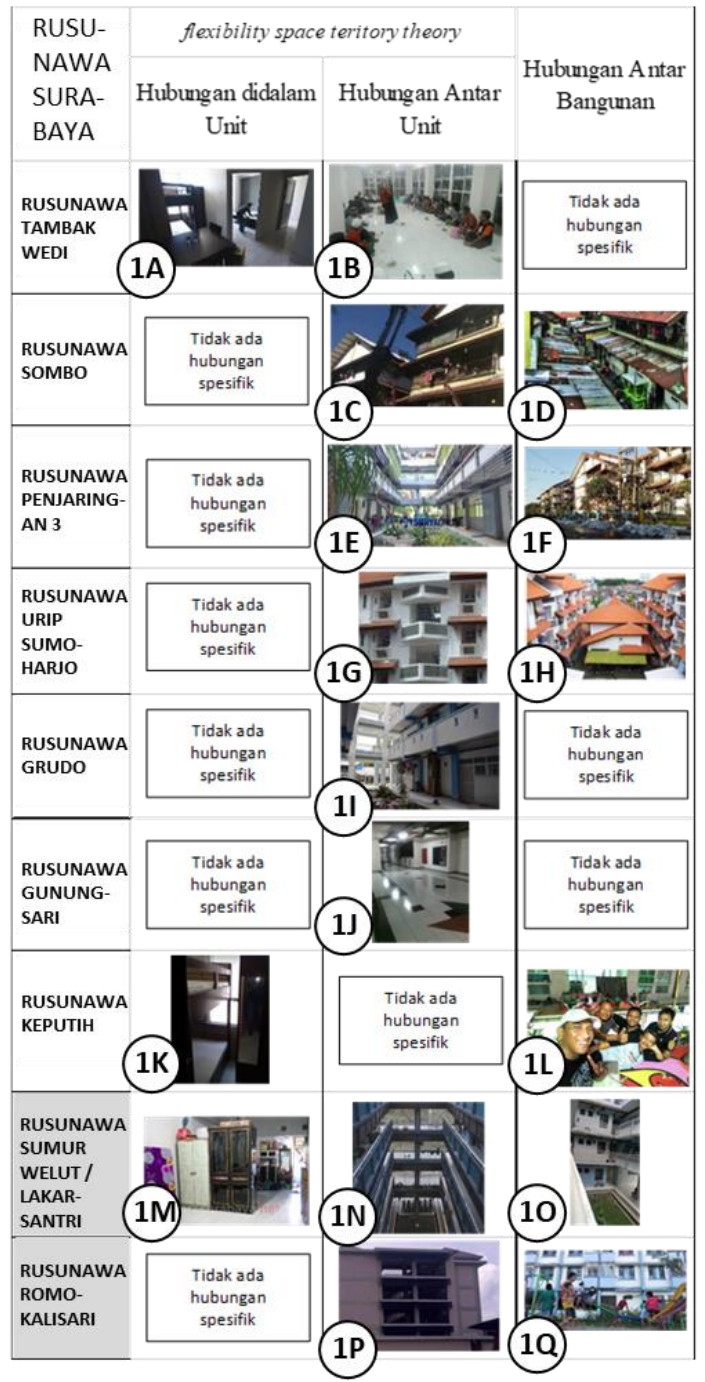

Tabel 1. Hubungan Ruang (fleksibilitas dan teritori) pada Rusunawa di Surabaya. 
Sumber: (Bebi, 2019; Prasetyo, 2017; Supratini, 2019; Wastara, 2020; Zahro, 2017)

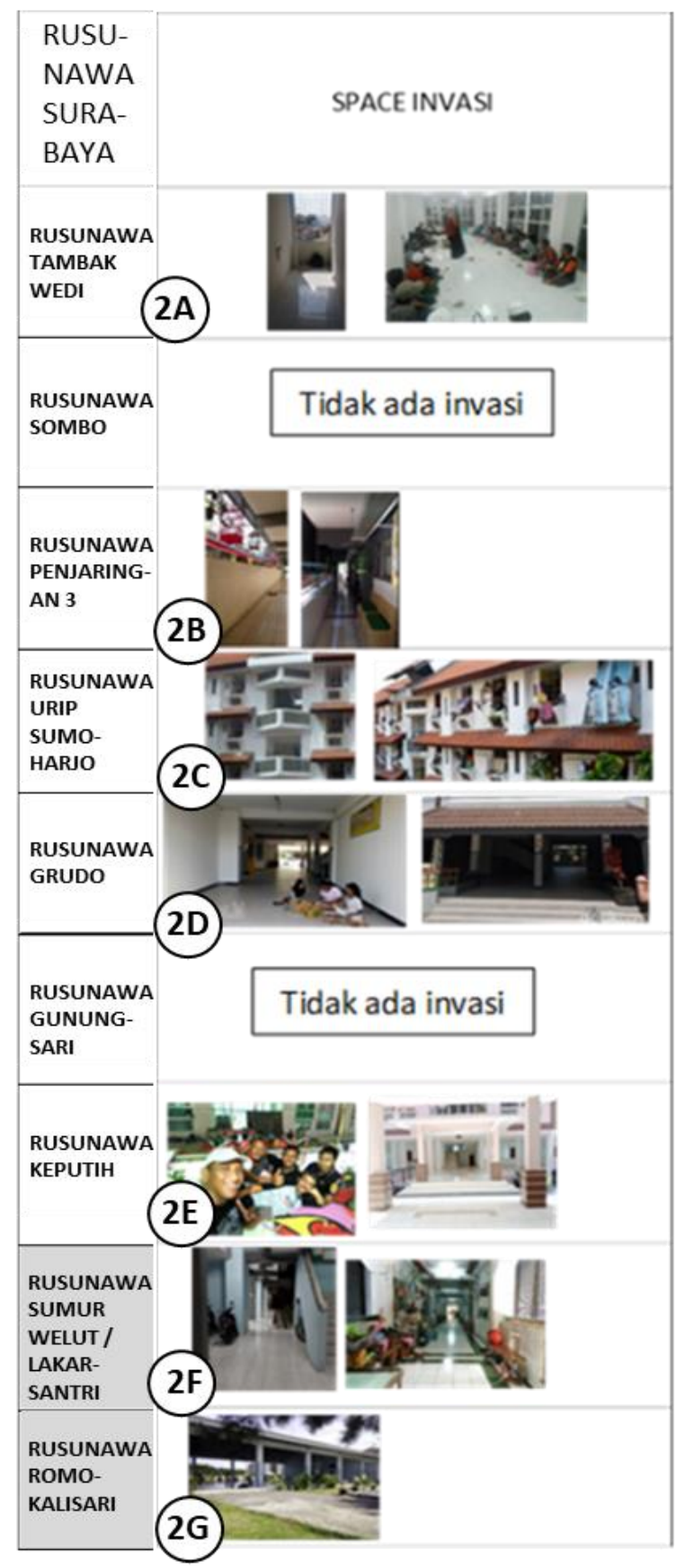

Tabel 2. Aktivitas invasi ruang di hunian Rusunawa. Sumber: (Bebi, 2019; Prasetyo, 2017; Supratini, 2019; Wastara, 2020; Zahro, 2017)

Dari Tabel 1 dan 2, terlihat adanya penggunaan ruang publik menjadi ruang personal terutama di area koridor. Penelitian Ramadhani et al., (2017) menemukan fenomena yang sama terjadi di hunian rumah susun dimana aktivitas domestik/pribadi pada waktu-waktu tertentu menggunakan ruang publik disamping kegiatan sosial/interaksi.

\section{"Eventuality space invasion" sebagai konsep perancangan.}

Fleksibilitas penggunaan ruang oleh warga terhadap huniannya dilakukan dengan menggunakan satu ruang untuk mengakomodasi beberapa aktivitas dengan penataan setting berbeda. Berdasarkan kajian preseden beberapa bangunan rusunawa di Surabaya dan observasi di perkampungan warga, hal ini merupakan kebiasaan yang mereka lakukan dengan aturan dan jadwal yang cukup fleksibel dengan kesepakatan antar penghuni/warga. Kegiatan invasi spasial dapat dilakukan karena adanya kebutuhan kegiatan/aktivitas sosial di lingkungan pemukiman sampai dengan aktivitas domestik di dalam lingkungan hunian. Dari uraian temuan di atas dijadikan sebagai perumusan kriteria dan konsep perancangan yaitu menerapkan ruang yang dapat diinvasi dengan beberapa aktivitas dalam kejadian tertentu (Eventuality space invasion).

Eventuality space invasion merupakan konsep dimana sebuah ruang dapat diinvasi pada waktu-waktu dan acara tertentu, ketika penghuni ingin melakukan aktivitas berhuni/domestik dan berinteraksi. Konsep ini tidak hanya diterapkan dalam perancangan skala mikro (di dalam unit hunian), tetapi juga skala meso (antar unit-unit) dan makro (antar bangunan di kompleks rusun). Area eventuality space invasion dibiarkan kosong untuk dapat digunakan oleh penghuni dengan berbagai aktivitas domestik (menaruh barang, bersantai, menjemur), maupun aktivitas sosial (bercengkrama, bermain, berinteraksi), ataupun acara-acara pada waktu tertentu 
(pernikahan, kematian, selamatan, pengajian, dan lain sebagainya).

Konsep ini juga dapat ditunjukkan dengan ruang yang dapat memiliki beragam makna, penamaan ruang, fleksibilitas penggunaan dan penataan setting untuk beragam kegiatan pada waktu yang berbeda. Hasil diskusi konsep eventuality space invasion kemudian didetaikan dengan mengajukan beberapa prioritas konsep perancangan (Gambar 4), sebagai berikut:

1. Neighboor view to house aperture: Pandangan tetangga / warga sekitar terhadap bukaan rumah.

2. Interactive space: Ruang interaktif sesuai dgn kegiatan yang dilakukan dan mengakomodasi perubahan - perubahan aktivitas penghuni karena pertumbuhan dan perubahan proses kehidupan.

3. Flexible Activity: Ekspresi invasi ruang adalah invasi ruang yang terjadi saat-saat terakhir/tertentu. Aktivitas antar penghuni yang fleksibel menciptakan ruang-ruang bersama berdasarkan waktu

4. Flexible Partition: melakukan penataan ruang secara fleksibel dan mudah dirubah dengan sekat/partisi dan perabot.

5. Open space and maximaze the shading: suatu ruang terbuka untuk mewadahi keempat prioritas lainnya, namun memberikan teduhan dan aman dari panas dan hujan.

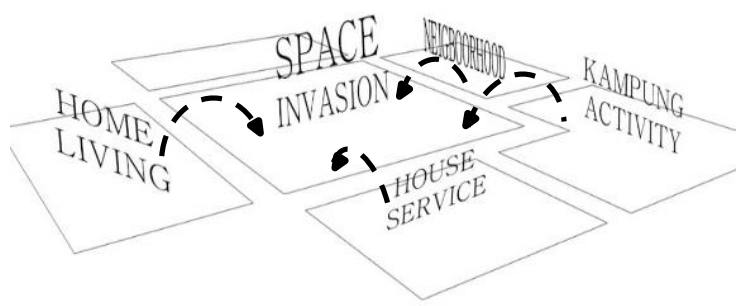

Gambar 4. Diagram Ruang Invasi sebagai konsep perancangan (Wastara, 2020)
Pengaplikasian konsep pada beberapa elemen arsitektur rumah susun

Dari hasil observasi dan kajian preseden serta didukung oleh hasil penelitian sebelumnya dan teori, maka telah dirumuskan lima prioritas perancangan untuk memaksimalkan ruang-ruang rusunawa agar dapat mengakomodasi aktivitas penghuni. Pada bagian ini merupakan hasil proposal rancangan skematik dari penggunaan ruang-ruang di rusunawa dengan aktivitas invasi spasialnya. Beberapa ruang yang dirancang adalah koridor, balkon dan halaman/courtyard rusun.

1. Balkon: Gambar 5 menunjukkan area dengan konsep eventuality space dan space quality based on human comfort. Balkon digunakan tidak hanya sebagai kegiatan-kegiatan domestik, namun terkadang terjadi invasi secara verbal/suara dan pandangan antar tetangga masih terjadi walaupun tidak mengganggu.

Aktivitas domestik yang diakomodasi di balkon diasumsikan aktivitas-aktivitas yang terjadi dibelakang rumah permukiman di sempadan sungai, seperti menjemur baju dan bersantai. Aktivitas menjemur dapat didukung dengan memberikan elemen partisi. Partisi untuk menjemur berupa dua jenis, yaitu fasad unit di sisi balkon yang dibuka keatas dan digunakan untuk menggantung, dan papan jemuran yang dikaitkan pada railing balkon. Papan jemuran lebih memakan tempat, namun penggunaannya fleksibel dan mudah dipindahkan. Sedangkan, fasad unit sebagai jemuran tidak dapat dipindahkan, namun tidak memakan banyak tempat. Saat aktivitas domestik ini tidak dibutuhkan dan penghuni ingin membatasi privasi dari huniannya, fasad pada setiap unit dapat ditutup agar meredam suara dan membatasi akses secara visual. 

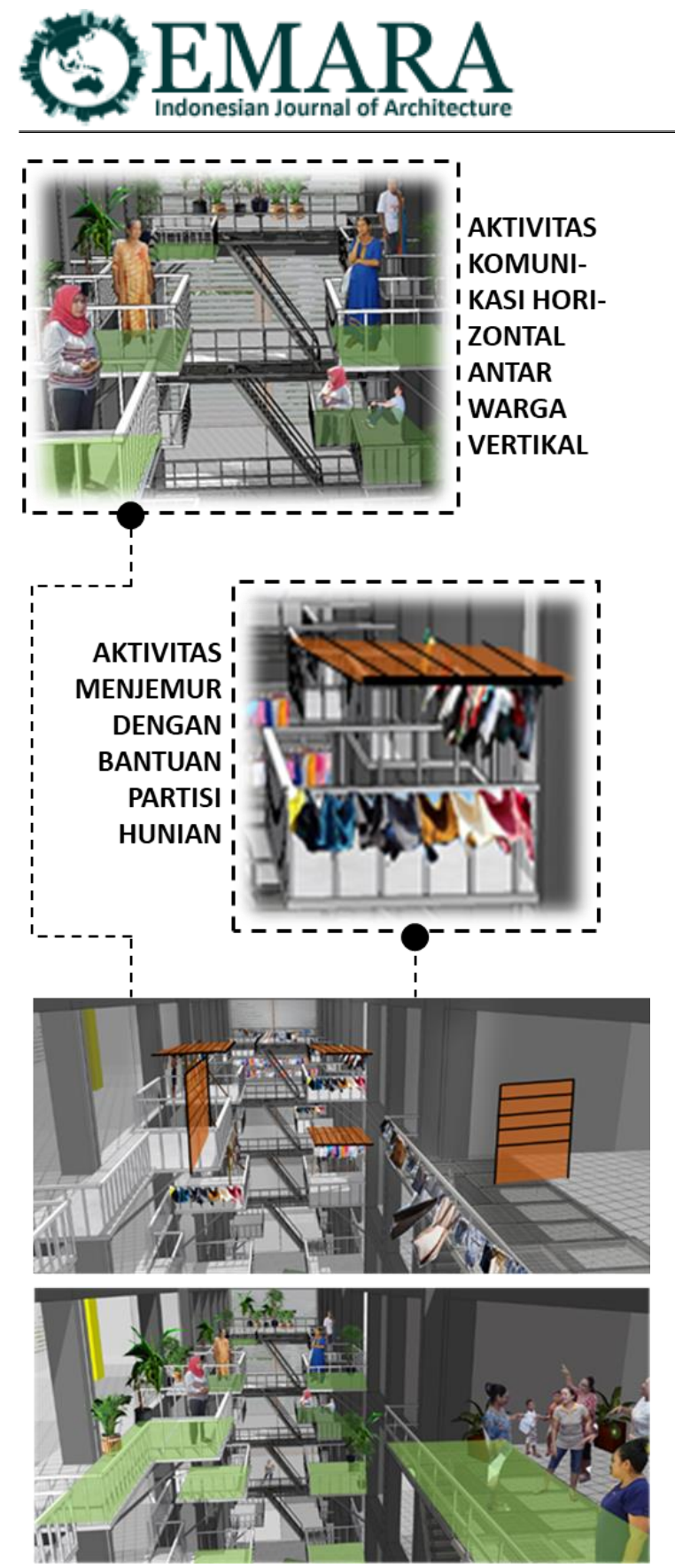

Gambar 5. Aktivitas Eventuality Space Invasion di balkon rusunawa (Wastara, 2020)

2. Koridor: area ini mengakomodasi kegiatan invasi ruang karena disediakan untuk dapat digunakan untuk aktivitasaktivitas kolektif. Invasi yang dilakukan pada area ini memerlukan kesepakatan dan perjanjian untuk waktu dan jenis aktivitas yang dilakukan oleh setiap penghuni di lantai tersebut (Gambar 6).

Aktivitas yang terjadi disini adalah kegiatan invasi berbasis aktivitas sosial; berupa bermain, bercerita dan berbincang
ISSN 2460-7878 (print) - 2477-5975 (Online) jurnalsaintek.uinsby.ac.id/index.php/EIJA Vol 7, No 1, 2021

sesama tetangga, mengasuh anak dan lain sebagainya. Berdasarkan kesepakatan tertentu, aktivitas domestik juga dapat dilakukan di area ini, seperti menjemur baju bersama, memandikan anak bayi mereka, meletakkan peliharaan burung, dan menyimpan barang, dan lainnya.

Kemungkinan-kemungkinan aktivitas yang diwadahi adalah aktivitas domestik yang dilakukan oleh warga di area gang permukiman seperti anak-anak bermain, mencuci baju, memandikan anak, menjemur, meperbaiki barang rumah dan lainnya, dan aktivitas di area sempadan sungai seperti bersantai, mengupas sayur dan buah, mengasuh anak dan lainnya. Fasad yang menjadi kisi pada bangunan dapat dibuka dan ditutup oleh penghuni. Fasad sekitar koridor rusun dirancang cukup fleksibel yang dapat dibuka untuk aktivitas yang lebih publik. Sebaliknya, beberapa bagian fasad dapat ditutup ketika ingin melakukan aktivitas yang lebih privat untuk menghalangi pandangan dari sisi luar dan air hujan (Gambar 6).
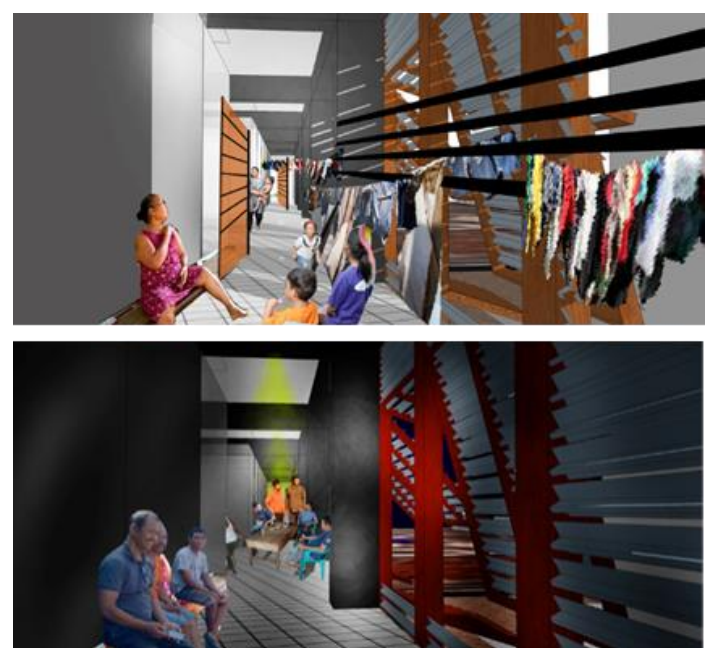

Gambar 6. Penggunaan elemen fasad fleksibel untuk aktivitas kolektif (Wastara, 2020)

3. Halaman/Courtyard: Area courtyard bangunan di lantai dasar sebagai area eventuality space invasion 
dengan menghadirkan area panggung di pusat void rusunawa dibawah area transportasi vertikal/tangga (Gambar 7). Pada area courtyard, kegiatan invasi ruang dilakukan untuk aktivitas sosial yang dilakukan oleh penghuni antara lain acara arisan, rapat RT, pertunjukan 17 agustus di panggung dan area bermain anak. Aktivitas-aktivitas sosial dan bersama yang terjadi di permukiman sempadan sungai juga dapat diakomodasi dalam kelompok kecil dan sedang seperti senam lansia dan senam pagi rutin dengan memanfaatkan penggung utama dan menambah panggung - panggung yang mudah dibongkar dan dipasang di area halaman rusun. Sisi koridor yang mengarah ke halaman tengah/courtyard dirancang untuk mengakomodasi kegiatan invasi ruang. Pada sisi tangga, disetiap lantai terdapat area berlebih yang disediakan untuk dapat diinvasi oleh aktivitas lain dengan kesepakatan bersama.

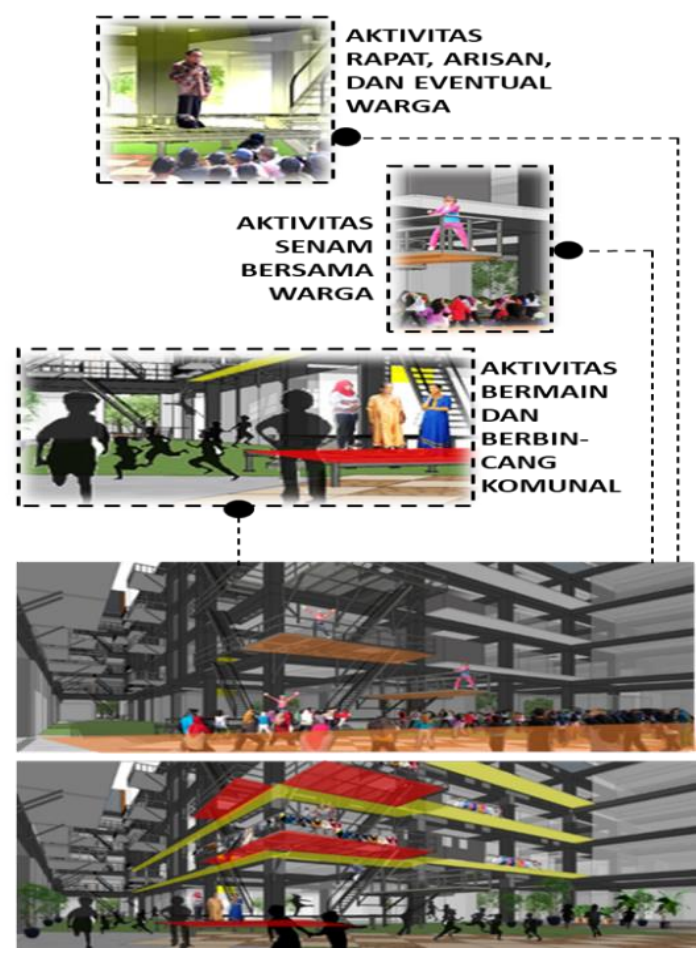

Gambar 7. Berbagai aktivitas sosial di area courtyard/halaman rusunawa (Wastara, 2020)
Dari ketiga usulan rancangan tersebut, terdapat satu aspek penting untuk mendukung konsep perancangan dimana baik di area balkon, selasar dan halaman diberikan area hijau atau penambahan vegetasi. Hal ini tidak hanya memenuhi kebutuhan ruang terbuka untuk memasukkan penghawaan alami, namun juga memberikan peluang penghuni untuk dapat berinteraksi dengan lingkungan alami. Penggunaan ruang-ruang publik yang cukup fleksibel terutama untuk kegiatan-kegiatan sosial menjadi poin penting dalam mengusulkan konsep perancangan. Hal ini juga didukung oleh Ernawati (2019) yang merumuskan faktor kepuasan tinggal di rusun antara lain faktor teknis bangunan yang menyediakan RTH dan fasilitas umum serta faktor kehidupan sosial terutama interaksi sosial antar penghuni.

\section{Kesimpulan}

Penelitian ini membahas aktivitas penggunaan ruang dan invasi ruang tidak hanya berdasarkan hasil observasi/fakta empiris di permukiman sempadan sungai, tetapi juga didukung dengan studi preseden dari beberapa rumah susun di Surabaya. Aktivitas invasi ruang dan penggunaan ruang secara fleksibel merupakan salah kebutuhan masyarakat untuk mengakomodasi keberagaman aktivitas domestik, ekonomi dan sosial. Berdasarkan aktivitas warga yang saling menginvasi dan keragaman penggunan ruang di dua tipe hunian (kampung dan rumah susun), ruang fleksibel di bangunan hunian kolektif dapat disediakan beragam dan fleksibel bagi warga. Penelitian ini memiliki batasan dimana kajian preseden 9 (sembilan) rumah susun di Surabaya tidak seluruhnya dilakukan melalui observasi langsung, tetapi dengan merujuk beberapa gambar/foto kegiatan yang diambil dari beberapa sumber media massa. Disamping itu, kegiatan invasi 
ruang juga hanya diobservasi dan dieksplorasi di lingkungan permukiman marginal/sempadan sungai yang kemungkinan batasan serta potensi kegiatan tersebut tidak sama dengan konteks permukiman lainnya. Sehiggan, penggunaan ruang perlu diatur dan dirancang dengan memperhatikan karakter gaya hidup warga, kesepakatan warga, dan ketersediaan material/elemen arsitektural yang fleksibel untuk dapat dilakukan perubahan dan penataan ruang sesuai kebutuhan penghuni. Untuk penelitian lanjutan akan lebih kaya jika melakukan investigasi lebih dalam melalui penelitian dalam konteks lingkungan permukiman yang lebih luas dan berbeda. Hal ini memungkinkan untuk mendapatkan kriteria perancangan hunian vertikal kolektif yang lebih beragam dan mungkin berbeda sesuai dengan konteks sosial, ekonomi dan budaya penghuni.

Rekomendasi untuk praktek lanjutan pada penelitian ini adalah perancangan program ruang dapat diteliti lebih dalam dengan melakukan wawancara lebih mendalam dan spesifik pada beberapa partisipan dengan metode menunjukkan beberapa usulan rancangan dan partisipan akan memilih mana rancangan yang sesuai dengan gaya hidup mereka. Hal ini dapat dilakukan dengan prototype 3D animasi atau gambar suasana dari pilihan ruang hunian vertikal yang ada. Selain itu, hasil penelitian ini dapat dikaji kembali terutama kaitan antara aktivitas invasi ruang dengan konteks masa pandemi yang harus menerapkan menjaga jarak individu dan sosial. Ekspresi dan kemungkinan merancang ruang bersama/ruang sosial akan menjadi berbeda dengan pola dan aturan berbeda pula untuk membatasi interaksi manusia dan transmisi virus pandemi. Selain itu, penelitian ini memberikan peluang menggali teori eksplanatori (explanatory theory) untuk mendukung konsep, parameter dan kriteria perancangan arsitektur berbasis penelitian empiris dengan pendekatan perilaku. Sehingga, hasil rancangan dapat menyesuaikan kebutuhan, keinginan, dan gaya hidup penghuni sesuai dengan konteks lingkungan, kondisi sosial, ekonomi dan budaya.

\section{Pernyataan penulis}

Dengan ini penulis menyatakan bahwa penelitian ini terbebas dari konflik kepentingan dengan pihak manapun

\section{Ucapan Terimakasih}

Penulis mengucapkan terimakasih kepada semua pihak yang telah mendukung penelitian ini.

\section{References}

Baum, A., Riess, M., \& O’hara, J. (1974). Architectural variants of reaction to spatial invasion: Environment and behavior. Environment and Behavior, 6(1), 125-125.

https://doi.org/10.1177/0013

91657400600113

Bebi. (2019). Rusunawa Sombo Kumuh, Risma Ambil Cat, Sapu lalu Lakukan ini Bersama Para S. Surabayapagi.Com. https://surabayapagi.com/rea d/rusunawa-sombo-kumuh-risma-ambil-cat--sapu-lalulakukan-ini-bersama-parastafnya

Ćetković, A. (2012). Flexibility in architecture and its relevance for the ubiquitous house. Technoetic Arts, 10(2-3), 213219.

https://doi.org/10.1386/tear.1 0.2-3.213_1

Creswell, J. W. (2014). Research Design: Qualitative, Quantitative, and 
Mixed Methods Approaches (4th ed). SAGE.

Das, A. (2015). Slum upgrading with community-managed

microfinance: Towards progressive planning in Indonesia. Habitat International, 47, 256-266. https://doi.org/10.1016/j.habi tatint.2015.01.004

Das, A. (2017). A City of Two Tales: Shelter and Migrants in Surabaya. Environment and Urbanization ASIA, 8(1), 1-21. https://doi.org/10.1177/0975 425316686501

Ernawati, R. (2019). Faktor yang Mempengaruhi Kepuasan Tinggal pada Rusunawa di Kota Surabaya. Emara: Indonesian Journal of Architecture, 5(1), 24-31.

https://doi.org/10.29080/eija. v5i1.527

Frick, H., \& Mulyani, T. H. (2006). Arsitektur ekologis: Konsep arsitektur ekologis pada iklim tropis, penghijauan dan kota ekologis, serta energi terbarukan OPAC Perpustakaan Nasional RI. Penerbit Kanisius. https://opac.perpusnas.go.id/ DetailOpac.aspx?id=536367

Haryadi. (2010). Arsitektur, lingkungan, dan perilaku: Pengantar ke teori, metodologi, dan aplikasi. Gadjah mada University Press.

Hutagalung, A. s. (2007). Dinamika pengaturan rumah susun atau apartemen. Jurnal Hukum \& Pembangunan, 34(4), 317-330. https://doi.org/10.21143/jhp. vol34.no4.1443

Jormakka, K., Schürer, O., \& Kuhlmann, D. (2014). Basics Design Methods. Walter de Gruyter $\mathrm{GmbH}$.
KBBI. (n.d.). Definisi Invasi. Retrieved 27 December 2021, from https://kbbi.kemdikbud.go.id/ entri/invasi

Kisnarini, R. (2015). Functionality and adaptability of low cost apartment space design: A case of Surabaya Indonesia. Technische Universiteit Eindhoven.

Kopec, D. (2018). Environmental Psychology for Design. Bloomsbury Academic.

Kronenburg, D. (2007). Flexible: Architecture that Responds to Change. Laurence King Publishing.

Lianto, F., \& Dwisusanto, B. (2015). Teritorialitas dan keamanan penghuni pada permukiman horisontal dan vertikal (rumah susun sederhana), [studi kasus: Rumah susun sederhana sewa (rusunawa) bumi cengkareng indah, jakarta]. Jurnal Sosial Ekonomi Pekerjaan Umum, 7(3), 219-228.

Maslow, A. H. (2010). Toward A Psychology of Being-Reprint of 1962 Edition First Edition. Martino Publishing.

Pemkot Sutrabaya. (2017). Visi Misi Walikota RPJMD 2016-2021. https://surabaya.go.id/id/page /0/37273/visi-misi-walikotarpjmd-2016-----2021

Plomp, T. (2007). Educational Design Research: An Introduction. Seminar on 'Educational Design Research', China.

Plowright, P. D. (2014). Revealing Architectural Design: Methods, Frameworks and Tools. Routledge.

Prasetyo, S. (2017). Suka-Duka Urus Administrasi Penghuni Rusun, Pengaduan Cepat tapi Bayar Lelet. Jawapos.Com. 
https://www.jawapos.com/me tro/metropolis/07/01/2017/s uka-duka-urus-administrasipenghuni-rusun-pengaduancepat-tapi-bayar-lelet/

Ramadhani, A. N., Faqih, M., \& Hayati, A. (2017). Behaviour Setting and Spatial Usage Analysis on Sombo Low Cost Flat's Corridor. Journal of Architecture \& Environment, 16(1), 61-74. https://doi.org/10.12962/j235 5262x.v16i1.a3189

Ramadhani, A. N., Hayati, A., \& Faqih, M. (2019). The Effect of Physical Quality Improvement to Inhabitant's Sense of Place. EMARA: Indonesian Journal of Architecture, 5(1), 32-40. https://doi.org/10.29080/eija. v5i1.656

Supratini, D. A. (2019). Waduh! Ratusan Penghuni Rusunawa Tak Mau Bayar Uang Sewa. Info SUrabaya.

https://infosurabaya.id/2019/ 01/09/waduh-ratusanpenghuni-rusunawa-tak-maubayar-uang-sewa/

Wastara, J. G. (2020). Fleksibilitas ruang sosial: Perancangan hunian kolektif dengan gaya hidup sempadan sungai [Masters Thesis, Institut Teknologi Sepuluh Nopember]. https://repository.its.ac.id/798 $50 /$

Zahro, F. (2017). Banyak Bangunan Liar di Rusun Sombo, ini yang Akan Dilakukan Pemkot Surabay. https://surabaya.tribunnews.c om/2017/08/27/banyakbangunan-liar-di-rusunsombo-ini-yang-akandilakukan-pemkot-surabaya.

\section{Kontribusi Penulis}

Joshua Gama Wastara berkontribusi pada persiapan konsep penelitian, metodologi, investigasi, analisis data, visualisasi. penyusunan dan revisi artikel

Arina Hayati berkontribusi pada persiapan konsep penelitian dan tinjauan pustaka, analisis data, persiapan,validasi dan revisi draf artikel 